\title{
SOCIAL STATUS OF NON-ROYAL WOMEN THROUGH THEIR NON-RELIGIOUS OCCUPATIONS IN ANCIENT EGYPT
}

\section{ENGY EL-KILANY \\ SAMAR MOSTAFA KAMAL \\ FACULTY OF TOURISM AND HOTELS, MINIA UNIVERSITY}

\begin{abstract}
Women in ancient Egypt were distinguished and had many privileges and rights comparing to their counterparts in the other ancient societies. Their social status was determined according to many indicators such as their families, husbands, relationships, wealth, occupations, education and skills.

This paper aims to explore the social status of Non royal women according to their non -religious occupations. This study depends on visual and textual evidences. It examined many tombs from different periods and different locations to determine the female occupation of non-royal and non-religious. Additionally; it detected female titles as well as analyzing scenes captions, titles and letters as textual sources. This study applies descriptive and analyzing methodology to achieve its aims.

Results of this study reveal that women who were involving in music career and weaving industry enjoyed a very high social status in the Egyptian society while those who were involved in baking, brewing, domestic and agriculture services are the less of all occupation
\end{abstract}

KEYWORDS: women- occupations- Ancient Egypt.

INTRODUCTION

The status of women changed over the millennia and in most periods they hardly appeared in administrative positions and higher offices. Nerveless there are many exceptions especially during the late period (Grajetzki, 2018). Although ancient Egyptian women enjoyed more freedom than the most of their counterpart in the ancient world, their opportunities for work were not the same as men. The range of occupation open to females was dependent on their social status (Lacovara, 2017).

Ancient Egyptian women in general were able to exert certain amount of influence outside the domestic sphere. Many scenes of everyday life illustrate wives who are depicted taking part with their husbands in their business activities. Moreover ancient Egyptian women enjoyed the same rights under the law of ancient Egypt (Watterson, 2013) It was desirable in 
The ancient Egyptian society that many women should receive the formal education that would enable them to join a career outside home either in the civil service or as a holders of public office, or to be trained for employments artisans and craftsman (Watterson, 2013).

This paper aims to explore the social status of ancient Egyptian women through their occupation. It excludes religious occupation as it is obviously known that women of religious career were highly appreciated in ancient Egyptian society. This study depends on visual and textual evidences. It examined many tombs from different periods and different locations to determine the female occupation of non-royal and non-religious. Additionally; it detected female titles as well as analyzing scenes captions, titles and letters as textual sources. This paper is divided into two parts. The first one displays women occupations in ancient Egypt while the second part discussed the social status of each occupation in the society. The woman's role within the domestic units in settlements must have been conspicuous. One of the most common titles in all times and places is "Lady of the House" nbt pr, which implies the management of the home and servants, whether it was a small household or a large estate that encompassed business, trade, and personal areas. This role is known through textual evidence but is far less visible in the actual archaeological remains. Documentary evidence from letters, administrative texts, and scene captions reveals that in reality women held important positions outside the home as priestesses, temple workers, managers, and producers of linen (Szpakowska, 2012).

Representation of non-royal women falls into two broad classifications. The first one depicts women from upper and middle classes, who were usually identified by name. They were wives, mothers and daughters of government or army officials and temple bureaucrats. They usually depicted supervising activities come under their authorities as mistresses of the house. They also played important roles in the religious cults as priestesses, singers, dancers, musicians, and observers in the cult of various deities as Amun, Khonsu, Pakhet, Neith and Hathor (Szpakowska, 2012). The second classification depicts women from lower class of the society who were usually not identified. They were depicted as servants of the wealthy for food and drink preparations. They were also depicted involved in the all stages of the industrial craft of linen textiles and in many other occupations ((Tyldesley, 1993; Lacovara, 2017).

\section{WOMEN OCCUPATIONS IN ANCIENT EGYPT}

Female occupations of non-royal women were divided into three categories according to El-Kilany, firstly is the performance group, which includes dancers, clappers, singers, musicians and mourners. Secondly is the 
productive group such as spinners, weavers, bakers, brewers, perfumers and potters. Lastly is the service group as domestic service, agriculture service and nursing service (El-Kilany, 2007).

\section{1-THE PERFORMANCE GROUP}

\section{1-A- DANCERS AND CLAPPERS}

Dance is considered to be the most common occupation for woman all over the world. That's because dance and music are the main source of entertainment and recreation. Women are the best for providing this recreation with no competitors. In ancient Egypt dancing was one of the most important features of their life. All dance scenes depicted in their tombs and temples represent moment of sadness or moment of joy, because dance was the hinge of both (Lexova, 1935; Meeks, 2001).

Clever female dancers may hold the titles of Supervisor of dancers' wrt hbw, Supervision of dancers of the king, Overseer of the harem of the King, Overseer of entertainment wrt hnr nsw. These titles were held only at the time of the Old Kingdom (Fischer, 1976). There is a scene in the mastaba of Khafkhufu II, (5 $5^{\text {th }}$ Dynasty, Giza G 7150) of a woman wearing a long dress and a wig precedes the dancers, and engaged with jewelers offerings in the chest in front of her, (Figure, 1). She is receiving something like gold ornaments as a kind of rewarding from the dancers (Simpson, 1978). Fischer mentioned that she is giving the signal to begin to dance and the word $s b^{3}$ is associated with her gesture and it is a designation of the woman who was the "instructress" of the dancer. Fischer also mentions that this is the first piece of written evidence for an instructress, but several women of the same period were known to have been "overseer of dancers" wrt hnr (Fischer, 1983).

During the Middle Kingdom, the role of female dancer is still important although there were no titles concerning female dancers. We still can feel the important role of female dancers by the elegant and respectable style of dressing, (Figures 2,3), (Vandier, 1964) as well as through the dancing class which represents female teachers and instructors, (Figure 4), (Vandier, 1964; Blackman, 1924) which ensure the talents and abilities of Egyptian female dancers. During the New Kingdom period many fragments especially at Deir El Madina related them with prostitutes (Meeks, 2000; Lexova, 1935). Whether the role of female dancer was appreciated, it was the most important occupation of woman in ancient Egypt. 


\section{1-B MUSICIANS AND SINGERS}

The sound of music was everywhere in ancient Egypt. Female musicians were represented as instrumentalists, both as soloists and in orchestras, (Figure 5) as singers and rarely as music directors, (Figure 6), (Manniche, 1991). Musicians were highly appreciated and honored in the Egyptian society, with evidence support this statement. Female musicians held many titles relating to music career such as Overseer of the singers, Overseer of every goodly entertainment of the king, Overseer of the harem, (Fischer, 1976).

In the Middle Kingdom period, named musicians appeared largely, such as the tomb of Antefaker at Thebes (Davies, 1920) there is name of Khuwyt the female singer and harpist at the same time. She is represented with male musicians. They were identified as the singer Didumin and the songstress Khuwyt, called in, to entertain the vizier in perpetuity with their songs about Hathor, the golden goddess, and about the vizier himself wishing him life and health (Manniche, 1991). Moreover, some texts mentioned that many deities were performing music which also indicates the importance role of female musicians, (Teeter, 1993).

During the time of the New Kingdom musicians were regarded according to the instrument they play. The harp was the master of ancient Egyptian instrument, and then came the other instruments, (Figure 7). (Manniche, 1991)At that time there was great difference between musicians, some of them were highly appreciated and other were of law social regards. For example some female musicians belong to the upper class and the royal family who serve in temples and palaces were highly appreciated (Szpakowska, 2012). Many females playing lute are represented almost naked and others with lyre, appear with the tattoo of God Bes on their thighs. In the New Kingdom, prostitutes were never depicted in tombs, but there were many representations of this work at the ostraca especially from Deir El Madina. There are few wall paintings representing female musicians with the tattoo of God Bes, (Figure 8), and this may be a sign that these women were also involved in this occupation beside being a musicians (Manniche, 1997).

\section{1-C- MOURners}

The most important role in the funeral ritual was played by two women chosen to impersonate the two mourners (drty). The origin of these traditions goes back to the Osirian legend as the Egyptians were in deep sorrow and grief for the death of their god. His two sisters Isis and Nephthys mourned and lamented him. The one kneeling upon his head was called. $(\underline{d} r t w r t)$ the great mourner, who was Isis. While the other one 
kneeling at his feet was called ( $\underline{d r t} s r f$ ), the lesser mourner who was Nephthys, (Nureldien, 1985).

Professional mourning was one of the few public occupations open for woman. They were hired to follow the funerary procession and doing their display of wailing, screaming, raising their hands, throwing dust over themselves and the other traditional gesture of mourning the dead, (Figure 9). They were haired to do their noisy and hysterical performance as an essential part from the funeral procession (Zeinelabedeen, 2017).

We only have one title from the Old Kingdom related to female mourner which is, Overseer of mourner (Fischer, 1976). That title may indicates that mourning career is an organized system which provides women joining it privilege more than other women. At the time of the New Kingdom and with limitless number of depictions for that topic, it seems that female mourners were increasingly demanded and hired. Depicting the wife of the dead mourning her husband was another indication to the reputable character of the female mourners (Werbrouck, 1938). During the New Kingdom there were many depictions of mourning young girls and children accompanying their professional morning mothers such as the tomb of Ameneminet, (Figure 10) and the tomb of Ramosa (Zeinelabedeen, 2017).

\section{2- PRODUCTIVE GROUP}

\section{2-A- SPINNERS AND WEAVERS}

Textile figured prominently in all aspects of ancient Egyptian life. They were needed from the cradle to the grave. (Gillian, 2000, 286). During most of ancient Egyptian history, linen was the basic material used for textile. Ancient Egyptian women were the backbone of the industry of linen textile. Spinning is the twisting together of a fiber in order to produce a long organized length which is slightly elastic. The flax fibers were given a loose twist, and then they were actually spanned either into balls or into coils to produce the thread. Weaving is the process of interacting two or more sets of threads to produce all part of textile. (Bagnall. and Cribiore, 2006).

All scenes depicted in tombs give us information about the work shop of spinning and weaving. Women were not depicted neither working in making ropes or nets like men in ancient Egypt nor in wool production like woman in the Greco-Roman period.( Bagnall and Cribiore, 2006).

In the Old Kingdom, there is no representation of female spinners and weavers, but there were many evidences of the domination of women in this industry. Firstly, there was a representation of women accepting payment for finished cloth at the tomb of Akhethotep from the $5^{\text {th }}$ Dynasty. They were usually rewarded in gold (Ziegler, 1993). Secondly, the Old 
Kingdom hieroglyph word for weaver is a seated woman holding a shuttle or weaver sword (Fischer, 2001).

Thirdly, Women also have many titles concerning this career at the time of the Old Kingdom such as Overseer of the weavers house and Overseer of the house of weavers of the residence (Fischer, 1976), Overseer of ornaments, Overseer of Cloth (Fischer, 2000).

In the Middle Kingdom, men started to work at this industry; women no longer have important titles but still can be represented as supervisor of only female workers at the weaving work shop (Figure 11), such as the female supervisor at the tomb of Khnumhotep II at Beni Hasan (Kanawati \& Evans, 2016). In a letter from the Middle Kingdom town of Lahun, a woman writes to the lord of the estate about weaving women who refuse to work, and offers an excuse that 'there aren't any clothes, because my responsibility is directed to the temple - the threads have been set up, but cannot be woven!" The text here reveals a woman who does hold power, who supervises weaving women (who themselves have the confidence to refuse to work), and who holds a position of responsibility in the local temple (Szpakowska, 2012). In the New Kingdom, it seems that men replaced women in this occupation. Women were still depicted as spinners and weavers but with very limited numbers (Tavares, 2004). Their clothes are also an indication to the deterioration of their status at that period.

\section{2-B BAKERS AND BREWERS}

The ancient Egyptian usually depicted baking and brewing together and that's for many reasons. Firstly, bread and beer were made from the main agricultural products, wheat and barley, although wheat was not produced with large quantities till the beginning of the New Kingdom. (Bryan, 2004) Secondly, similar technology was applied at many stages. Lastly, the basic ingredients were the same (Delwen, 2000).

Female bakers and brewers were depicted in a large number of scenes in the private tombs during all periods especially during the Old Kingdom. There are many figures of them expedited in the Egyptian museum within the collection of the servant statues. Dressing style does not differ from time to time. They usually wear only short skirt and head band knotted at the back of their shoulder. They were depicted with shoulder straps dress and do not cover their hair. They also represented in a reddish brown color which is an important features of representation of servant in ancient Egypt, (Figure 12), (Robbins, 1993; Roehrig, 1996). 


\section{2-C Perfumers}

Perfume and fragrance industry is a very promising career for women in ancient Egypt. There are few scenes depicting female perfumers one from the Middle Kingdom tomb of Beni Hassan and another one from the late period. The Scene from Beni Hasan depicts group of five women well dressed, involving in the production of perfume. The first two were holding flowers in their hands and bags in the other hand. The second two seem to be squeezing the flower wrapped in a piece of cloth. The liquid comes from the squeezing is full into a pot. The last woman is standing in front of them smelling a flower; she seems to be their supervisor, (Figure 13), (Klebs, 1922). There is also a representation which dates back to the Twenty Sixth Dynasty of a group of women gathering lilies and another group squeezing the flowers for the making of perfume. All of them are represented with elegant dresses, hair styles and ornaments, (Figure 14), (Manniche, 1999).

\section{3- SERVICE GROUP}

\section{3-A AGRICULTURAL WORKS}

Through agricultural products, Egyptians can eat, drink and wear clothes. That is why it was very important to the ancient Egyptians to depict their agricultural activities in their tombs, such as plowing, sowing and harvesting.

Women who were involved in agriculture were divided into three types land mistress, estate managers and peasants. The first type who was the owner of agriculture land, the second type is female estate manager who usually works on the land of female owners while the third type was the very poor peasant woman who works in the field. This study is only concerned with the second and third type. As for the estate managers they were depicted during the Old Kingdom period. For example in the mastaba of queen Nebet (Saqqara, $5^{\text {th }}$ Dynasty) female administrators were shown, including a female state manager with the title of Overseer of the house. Another example was from the tomb of the wife of Merirouka at Saqqara, $6^{\text {th }}$ Dynasty. She had her own female state manager as well as a female overseer of the linen and a female inspector of the treasure. They are usually depicted in the tomb of their female superiors. They may appear at their own monuments such as Maatkheru who appeared with her husband on a false door in their mastaba at Giza depicted with the title of overseer of the estate (Grajetzki, 2018).

Harvest was the only activity that women were involved (Roehrig, 1996). There were many scenes in the Old Kingdom depicting women in the agricultural service, such as winnowing and sieving of grain which at first 
was exclusively a women's work. In the New Kingdom there was few representations of female working in the field at the time of harvest, (Figure 14). Most of it was pulling the staff, pitching the straw, gleaning and tidying up. Most of these depictions date back to the Eighteenth Dynasty (El-Kilany, 2007).

\section{3-B DOMESTIC SERVICE}

Servants are very important features of Egyptian houses of wealthy and moderate classes. Female servants are widely spread in Egyptian house with male servants too. They were responsible to do almost everything at home. They should do the cleaning, dusting, washing, cooking and most of all presenting food and drinks. Maid servants are sometimes responsible for the hair dressing and body care of her mistress. Moreover; they were depicted offering food and drink, carrying the funerary furniture of their mistress, preparing the bed and cushions as well as offering flowers and perfume especially at the banquet scene of the New Kingdom ( الوشاحى، 1985). Clever maid servants may be up graded to have some important title concerning this occupation (especially at the time of the Old Kingdom, such as: Steward, Director of dining hall and Overseer of the chamber of wig (Fischer, 1983).

Their clothes were very simple in the Old and Middle Kingdom the traditional white long dress, (Figure 15). In the time of the New Kingdom, they are usually represented nude, sometimes with the common long fitted dress. Sometimes they wear wrap-around dresses or bag tunics. They seem to be tidy and elegant comparing to servants in the previous periods, (Figure 16), (El-Kilany, 2007).

Concerning hairdressers, in the tomb of Nefru TT 319 at Deir El-Bahri, at Thebes there are two scenes representing two female hairdressers called Inw and Henut. The first scene represents the hairdresser Inw, was holding a lock of hair ready to insert into the coiffure of her mistress, Nefru. The second scene, the hairdresser Henut, holds a lock of Nefru's hair (Soliman, 2009). They seem to be from a better social standard than other women involved in the domestic service are. That is because both of them have their names and professions carved above their figures which are Inu the hairdresser and Henet the hairdresser. They are well dressed and elegant. They are representing standing and at the same scale of their mistress, (Figure 17). 


\section{3-C NURSING GROUP}

\section{3-C-1 MidWIVES}

The important female activity of which we have no visual evidence is midwifery. That activity is explained by the determinative, where the object held in the lap may represent one or both of the pair of blocks that served as a birth stool. The absence of representing human birth scenes would justify the lack of midwives iconographies, (Figure 18), (Fischer, 2000). This occupation is still found in the Egyptian village and is known by the word "Daya" - داية. In ancient Egypt it seems that midwives have medical training and also have organization career because there is a title of "overseer of midwives held by many women such as nefer-hete and Khenti-kauwes."(Fischer, 2001). There is also a decorated birth-brick from south Abydos which dates back to the $13^{\text {th }}$ Dynasty, (Figure 19). The scene on the brick's base depicts a seated mother holding a newborn baby in her arms. The mother is flanked by other two female figures. They seem to be helping her after her delivery. One of them is kneeling before the mother with her arms outstretched as if she is about to deliver the newly born child. The other one is placing a hand on her shoulder (Wagner, 2002).

\section{3-C-2 Physician}

There is only one title of female doctor but there is no one single evidence that woman really practice this occupation. She was Peseshet, Lady overseer of the lady-physicians at the tomb of Akhet-hotep from the $4^{\text {th }}$ Dynasty, (Ghaliongy, 1983). Recent study proofed that there is an error in reading this title and there is no existence of female physicians (Grajetzki, 2018).

\section{3-C- 3 WET-NURSE}

There were many representations of female suckling their babies but it was not clear whether they were mothers or wet-nurse (El-Kilany, 2007). Another title of importance was the 'Wet Nurse of the King' which could be held by wives of high ranking officials. The woman bearing this title was practically part of the royal family and her position would have given her royal favor as well as possible advancements for the male members of her family. The only represented wet-nurses were those of the Kings, queens and their children. They were represented suckling the king when he was a child, but the child is represented with full royal insignia. These representations, most of the times were depicted in the tombs of husbands or sons of the royal west-nurse. Rarely in her own tomb, such as Maya the wet-nurse of Tutankhamun at Saqqara and the scene of Amenemopet, is shown holding Amenhotep II on her lap. Above this scene is an 
inscription identifying Amenemopet as the 'Chief Nurse, Who Nurtured the God' (Fischer, 2000).

\section{3-C-4 NANNIES}

Nannies that were responsible for the bringing up of the children were also mentioned in tombs and were represented as members of the family, such as in the tomb of Idut at Saqqara in the Old Kingdom; a nanny was represented standing behind the princess. While in the Middle Kingdom employing nurses was not restricted to a certain class of the society. A nurse in the $12^{\text {th }}$ Dynasty held the title of the nurse of the god who is in the palace.(Nurel Dien,1985) ). In the New Kingdom the occupation of the nurse became more important and famous such as Raai the nurse of queen Ahmos Nefertary and Satre the nurse of queen Hatshepsut (Nurel Dien, 1985).

\section{RESULTS AND DISCUSSION}

The mainstream of ancient Egyptians, both men and women were illiterate and it was common in all ancient societies that women were more illiterate than men. The minority of the society in ancient Egypt was engaged in the bureaucracy or as artisans or craftsmen while the majority was deeply involved in agricultural works (Watterson, 2013). There is no evidence of female scribes; women could not take part in the government bureaucracy or in temple administration to a significant level (Fischer, 2000). As a male dominated society, the rules were created by men for the benefit of men. The dominance of men could control the public and political domain. Women in ancient Egypt whether rich or poor were less privileged in comparison to men of the same social class (Brown, 2010).

It is worthy to mention four debatable points. Firstly, that the absence of visual and textual evidence of certain occupations during certain periods does not mean it does not exist. Secondly, the status of those occupations differs from time to time as it will be explained later. Thirdly, as the majority of visual evidences were found in men's tombs so it is hard to tell whether the depictions express the real life of women or they were just a personal perspective of the tomb owner. Lastly, concerning titles as it is often difficult to tell which were honorific, which were held successively and which were earned.

Titles are important for they are perhaps the richest source for the various positions women might have held. Nevertheless, these titles have revealed the range of roles played by women in Ancient Egypt. (Szpakowska, 2012). The most important titles concerning female occupations are: Supervisor of dancers, Supervisor of dancers of the king, Overseer of the Harem of the King, Overseer of Entertainment, Overseer of Dancers, 
Overseer of the Singers, Overseer of every good entertainment of the king, Overseer of mourner, Overseer of the weavers house, Overseer of the weavers' residence, Overseer of Linen, Overseer of Ornaments, Overseer of Cloth, Overseer of the House Hold, Overseer of the Estate, Inspector of Treasure, Steward, Director of dining hall, Overseer of the chamber of wig, Overseer of midwives, Overseer of the lady-physicians, Wet Nurse of the King (Fischer, 1976, 2000, 2001).

In contrast to the Middle Kingdom, women of the Old Kingdom were engaged in many activities in an administrative level, as overseers of weavers, overseers of midwives, overseers of supplies such as food and cloth, overseers of dancers and more rarely of singer. In all cases where such titles refer to persons, the persons were other women (Fischer, 2000). Moreover; there are many scenes depicting women superiority, power, influence and authority over other group of women. For example the scene in the mastaba of Khafkhufu, ( $5^{\text {th }}$ Dynasty, Giza) which depicts her wearing a long dress giving the signal to begin to dance and the word $\mathrm{sb}^{3}$ is associated with her gesture and it is a designation of the woman who is the "instructress" of dancers (Fischer, 2000). In the Middle Kingdom tomb of Knumhotep II at Beni Hassan there is a representation of standing female in a long dress supervising a group of female spinners and weavers (Kanawati and Evans, 2016). Also in Beni Hassan, tomb of Baqet III, there is a scene of an old female supervisor holding a stick and over her head, the symbol of the $16^{\text {th }}$ nome of Upper Egypt is depicted punishing another woman in front of her, (Figure 20), (Kanawati and Evans, 2018). There is another scene from the tomb of Beni Hassan representing women supervising a group of females making perfume (Klebs, 1922). In the mastaba of queen Nebet (Saqqara, $5^{\text {th }}$ Dynasty) there is a depiction of female administrators including a female state manager. Another example is a depiction from the tomb of the wife of Merirouka at Saqqara, $6^{\text {th }}$ Dynasty; she had her own female state manager as well as a female overseer of the linen and a female inspector of the treasure (Grajetzki, 2018).

Code of clothing as a kind of non-verbal communication is an indicator of specific messages. Nakedness for example in Egyptian art has been read as representation of lower classes, servants, childhood or prostitutes. Therefor; clothes was used to indicate the social status of women through their occupations.

Although Old Kingdom figures show women making pottery, female potters seem to be missed from the artistic record after the Old Kingdom. As a result of that one should not assume that women are only involved in pottery making during the Old Kingdom, but rather that the conventions of 
representation changed. Women surely continued to make pots, but were no longer shown doing so. (Szpakowska, 2012).

As it was previously mentioned in the first part of this study, female occupations are classified into three main groups which are performance, productive and service groups. The total number of occupation within those groups is about twenty occupations. They are: dancers, clappers, musicians, singers, mourners, bakers, brewers, spinners, weavers, perfumers, potters, peasant women, maid servants, cookers, hairdressers, midwives, wet-nurses, physicians, nannies and lastly administrative supervisors.

\section{Performance group}

Includes dancers, clappers, musicians, singers and mourners.

The social status of female musicians is considered to be very privileged category specially those who played harps. This is confirmed from three evidences. Firstly, in the Old Kingdom many female musicians were honored by putting their names on the tombs of the other people, such as the judge Nikawre who commemorates the names of the famous musical female duo Hekenu the harpist and Iti her chironomist in his tomb (Manniche, 1991). It was a rare appreciation at that time. Secondly, many scenes were depicting the wife, the daughter or the sister of the tomb owner entertaining him by playing music. For example there is a scene in the tomb of Pepyankh-hery-ib at Meir from the $6^{\text {th }}$ Dynasty of two female harpists and a male flautist. The two harpists were the daughters of the male flautist (Blackman, 1924) as well as the famous scene, at Saqqara which dated to the $5^{\text {th }}$ Dynasty that of Merirouka who was entertained by his wife while playing the harp (Fischer, 2000). This indicates that playing music by the family of the deceased is something he was proud of, so he represented it in his tomb. On the contrary was dancing, as dancers were traditionally not family members of the tomb owner. Thirdly, the location of Old Kingdom tombs of musicians is near the royal pyramids at Giza also suggests that musicians were highly honored and appreciated. (Teetre, 1993).

The social status of dancers in Egyptian society differed according to the social habits of the period. Generally a female dancer enjoyed her occupation as an employee in the temple or in the palace which mean they have regular occupation and salary. She also can be up graded to hold a high title and position at this career. Some female dancers enjoyed a medium social status and it may be evident from their titles, elegant dresses, hairstyles and the dancing classes which appeared during the Middle Kingdom (Vandier, 1964; Blackman, 1924). During the New Kingdom, there was a little change of the social status of female dancer. 
We believed that her status deteriorated because they almost represented naked in sexy positions, and many fragments especially at Deir El Madina related them with prostitutes. Additionally; there are some texts show teachers warned their pupils against dance. (Meeks, 2001)

The social status of mourners differs from time to time. It is hard to tell their status during the Old and Middle Kingdoms due to the small number of visual and textual evidences relating to them. But during the New Kingdom it seems that female mourners enjoyed a good status which can be traced from their elegant dresses. Moreover; the depictions of mourning young girls and children accompanying their professional mourning mother such as the tomb of Amenemhat and the tomb of Ramosa (Zeinelabedeen, 2017). This indicates that female mourners were keen to make their children joining the same career because it seems to be a privileging career.

\section{Productive group inCludes}

Spinners, weavers, bakers, brewers, perfumers and potters.

The social status of weavers varies through times. In the Old Kingdom, where no men were involved at this industry at all, female weavers and spinners were highly appreciated and they were usually rewarded in gold. They also have many important titles and positions at this career. Although weaving was performed almost exclusively by women in the Middle Kingdom, something of that status may have been lost, for the term formerly applied to them was no longer used (Fischer, 2000). Their style of dressing is also an indication that female weavers were still enjoying some privileges from working in the industry of textile. They were depicted supervising female weavers and spinners. From the letter at Lahun it is evidenced that women enjoy large power and influence through this career (Szpakowska, 2012).

The social status of female bakers, brewers and potters seems to be very low and this is proved from their clothes, their reddish brown color and their humble work as they made great effort and yet were not rewarded enough in return.

The social status of perfumers seems to be much better than brewers, bakers and potters. They were represented with elegant dresses, hairstyles, pale cream color and moreover, their names were depicted above their heads (Manniche, 1991). 


\section{SERVICE GROUP}

includes agriculture, domestic and nursing services. The social status of peasant women who involved in agriculture work was very low in the Egyptian society. This can be terraced from the nature of their work and from their dressing styles. They seem to be poor and very simple people. They never have any titles or position in this occupation. We believe that they may work for part time or at least not all year around but only at the season of harvest. So they may not have regular salaries. They may be just simple house wives working at the season of harvest to improve the income of their families (El-Kilany, 2007). On the other hand women who involved of the management of the estate were considered to be women of power who were identified by titles with a very high status in the Egyptian society (Grajetzki, 2018).

The social status of maid servant was very low as the work of maid servant is simple and humble. Nerveless, woman with experience and certain qualities can have good social status (Tyldesley, 1993) and have some important titles concerning this occupation especially during the Old Kingdom. While the social status of hair dressers is much better than maid servants which was evident from their clothes, inscribed names and their scale of representation comparing to the scale of the mistress of the scene. The social status of midwives, wet-nurse and nannies is determined according to the people who they may serve. If they offered their services to kings, princess or nobles they would enjoy a high social status among their equivalents. If they offers their services to common people their social status would be minimized but still enjoy much better status than those of the domestic services. The term for midwives is unknown from later periods, and the Old Kingdom evidence is limited (Fischer, 2000).

\section{CONCLUSION}

Women in ancient Egypt were engaged in many occupations. Those occupations were classified into three groups according to nature of occupations. These categories are performance, productive and service.

Large number of women was engaged in occupation with low social status such as baking, brewing, winnowing, dancing, and domestic service. The minority who were engaged in administrative positions or involved in the music career, linen or perfume production or in nursing service occupation enjoyed a good social status varied from period to another.

Most cases women were producing their services in the retinue of wealthier women. The Social status of many occupations was determined according to the social class of the receiver of the service whether they were queens, nobles, elite, middle class, commoners, etc... 
Clothes, inscribed names, scene context, titles and textual evidences were the most important indicators to determine the social status of women occupation in Ancient Egypt. The absence of visual and textual evidence of certain occupations during certain periods does not mean it does not exist.

Concerning titles it is often difficult to tell which were honorific, which were held successively and which were earned. Old kingdom is considered to be the peak of the high social status of women through their occupation as the large number of titles was found during this period. The most common titles of women who were engaged in many activities in an administrative level were overseers of weavers, overseers of midwives, overseers of supplies such as food and cloth, overseers of dancers and more rarely of singer.

Although the social statues of non-royal women in ancient Egypt through their occupations varied from time to time and from occupation to another it must be remembered that women in ancient Egypt whether rich or poor were less privileged in comparison to men of the same social class.

\section{REFERNCES}

- Abdul-Kader M., 1966, The development of the funerary beliefs and practices displayed in the private tombs of the New Kingdom at Thebes, Ministry of culture, Cairo.

- Bagnall. R., and Cribiore,R., 2006, Bagnall.R.\& Cribiore,R., Women's Letters from Ancient Egypt, Michigan.

- Blackman, 1924, The Rock Tombs of Meir, vol. IV, VI London.

- Bryan, C., 2004, Cathie, "Bread and Bear", an essay in Ancient Egypt, Vol. 5, No. 2.

- Brown, C., 2010, Dancing for Hathor, Women in ancient Egypt, Continuum Books, London.

- Davies, N. de G., 1905, The Rock Tombs of El-Amarna III, London.

- Davies,N. de G. and Gardiner, A., 1920, THE Tomb of Antefoker, vizier of Sesostris and his wife Senet, London.

- Delwen, S., 2000, Baking and brewing an essay from the "Ancient Materials and Technology" edited by Nicholson \& Shaw, Cambridge.

- El-Kilany, E., 2007, Scenes Depicting Female Occupations in Ancient Egypt at the Private Tombs from the Old Kingdom to the End Of the New Kingdom, Minia University, Egypt, unpublished Ph.D theses.

- Fischer, H., 1976, Varia, Egyptian Studies I, Metropolitan Museum of art, New York.

- Fischer, H., 1983, Egyptian studies II. The Orientation of Heiroghlyphis, part 1 JEA, vol. 1, 69, 178-181. 
- Fischer, H., 2000, Egyptian Women of the Old Kingdom. New York.

- $\quad$ Fischer,H. 2001, Unique Composite Hieroglyph, in JARCE, vol.38, 1-6.

- Ghaliongy, P., 1983, P., "The Physicians of Paranoiac Egypt", Cairo.

- Gillian, V., 2000, Textile", in Ancient Egyptian Materials and Technology, edited by Nicholson and Show, Cambridge.

- Grajetzki, W., 2018, Meritptah: The world's first female doctor?, Ancient Egypt Magazine 111, December 2018, January 2019, 24-31.

- Hartwig M. (Ed), 3013, The Tomb Chapel of Menna (TT 69). The art, culture and science of painting in an Egyptian tomb: ARCE conservation Series 5, American University in Cairo Press.

- James, A. (2006). Some aspects of the non-royal afterlife in the Old Kingdom. The Old Kingdom Art and Archaeology: Proceedings of the Conference Held in Prague May 31 - June 4, 2004. Prague: Czech Institute of Egyptology.

- Kanawati, N. and Woods, A., 2010, Beni Hassan. Art and Daily life in an Egyptian Province, Supreme Council of Antiquities, Cairo.

- Kanawati, N and Evans, L., 2016, Beni Hassan, Tomb of Khnumhotep, vol.-- The Australian Centre for Egyptology: Report.

- Kanawati, N \& Evans, L., 2018, Beni Hassan, tomb of Baqet III, vol.IV, The Australian Centre for Egyptology: Report 42.

- Klebs,L., 1922, Die Reliefs und Malereien de mittlern Reiches, Heidelberg.

- Lacovara, P., 2017, The world of ancient Egypt: a daily life encyclopedia, Greenwood, Calefornia.

- Lexova, I., 2000, Ancient Egyptian Dances, Dover Publication, Prague.

- Manniche, 1991, Music and musicians In Ancient Egypt. London.

- Manniche, L., 1997, Sexual life in Ancient Egypt, London.

- Manniche,L., 1999, Sacred Luxuries: Fragrence, Aromatherapy and cosmetics in ancient Egypt, London.

- Meeks, D., 2001, Dimitri, Dance an essay in the Oxford Encyclopedia, vol.I.

- Newberry, P. E., 1893, Beni Hasan 2, London.

- Nureldien, A., 1985, The Role of Women in the Ancient Egyptian Society, Cairo.

- Robins, G., 1993. Women in ancient Egypt. London: The British Museum Press.

- Roehrig, C., 1996. Women's work: Some occupations of non-royal women as depicted in ancient Egyptian art. In: A. Capel and G. Markoe, ed., Mistress of the House, Mistress of Heaven: Women in Ancient Egypt, 1st Ed. New York: Hudson Hills Press Inc., pp.13-24. 
- Simpson,W., 1978, The Mastaba Of Kawab, Khafkhufu I\&II. vol.III, Boston.

- Soliman, R., 2009, Old and Middle Kingdom Theban Tombs, London.

- Szpakowska K., 2012. Hidden Voices: Unveiling Women in Ancient Egypt. In: S. James and S. Dillon, ed., A Companion to Women in the Ancient World, 1st ed. John Wiley \& Sons, Ltd., pp.25-37.

- $\quad$ Tavares, A., 2004, The Hidden Industry, AERA, vol.7.

- Teetre, E., 1993, Female musicians in Paranoiac Egypt, in Women's Musical Traditions, edeited by Kimberly Maeshall, Boston.

- Tyldesley, J, 1994, Daughters of Isis, Women of Ancient Egypt. Penguin.

- Vandier,J., 1964, Manuel D ‘Archéologie Egyptienne. Tom.iv, Paris.

- Wagner, J., 2002, A decorated Birth-brick from south Abydos, an essay in EES, n.21.

- Watterson, B., 2013,Women in ancient Egypt. Amberley Publishing, Gloucesrshire.

- Werbrouck, M., 1938, Le Pleureuses Dans L'Egypte Ancienne. Bruxelles.

- Ziegler, C., 1993, Le Mastaba D’Akhethetep. Paris.

- Zeinelabedeen, M., 2017, The Funeral Procession, A comparative Study between Saqqara Old Kingdom and Theban, New Kingdom Private Tombs, Minia University, Egypt unpublished PhD Thesis.

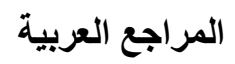

الوشاحي، مفيدة حسن ، 1989 ، مناظر الخدمة اليومية في مصر القديمة، رسالة ماجستير غير منشورة، كلية الآثار ، جامعة القاهرة، القاهرة.

Figures

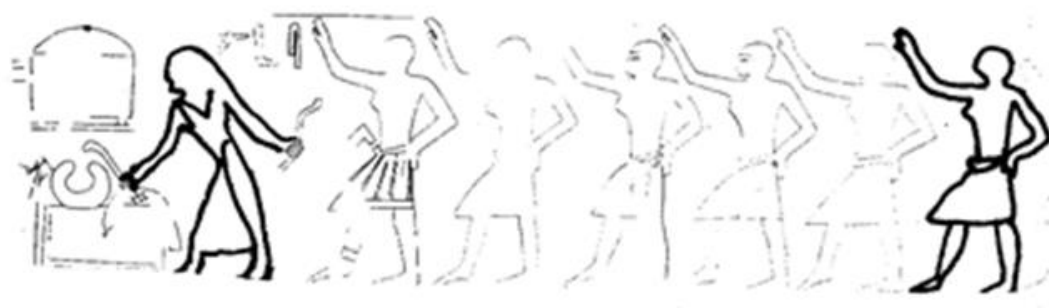

Figure 1. Dancers and female instructor $\mathrm{sb}^{3}$, (mastaba of Khafkhufu II (G 7150), east wall, 5th Dynasty, Giza.

Source: Simpson,W., 1978, The Mastaba of Kawab, Khafkhufu I\&II. vol.III, Boston, figure 48. 


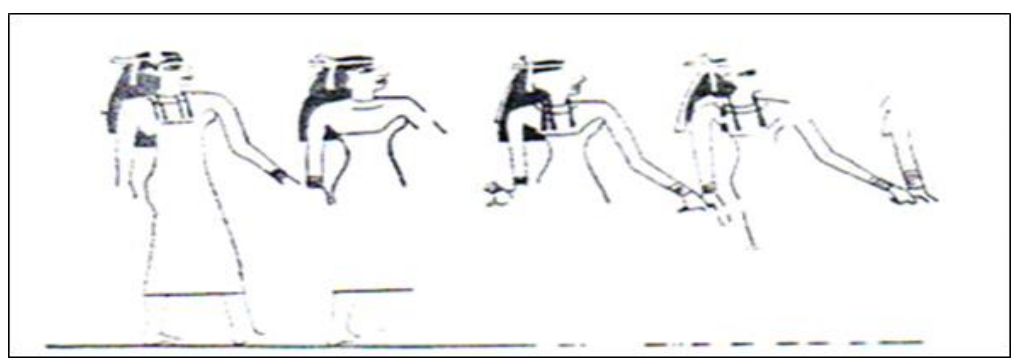

Figure 2. Female dancers with elegant dress and hair style, tomb of Ankhtifi, 11th Dynasty.

Source: Vandier,J., 1964, Manuel D ‘Archéologie Egyptienne. Tom. iv, Paris.

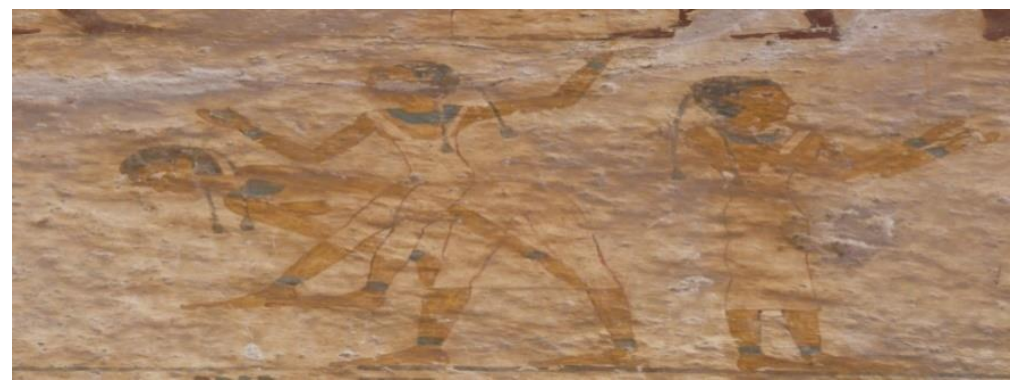

Figure 3. Female acrobatic dancers, tomb of Kheti (no. 17), north wall, Beni Hassan, 11th Dynasty, Middle Kingdom. Source: Photographed by the researcher

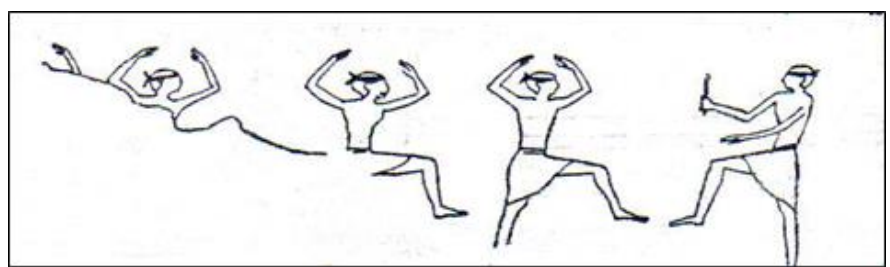

Figure 4. Female dancing class with an instructor leading them, tomb of Ahnakhet,12th Dynasty, El Bersha Vandier J., 1964, Manuel D’Archéologie Egyptienne. Tom. IV, Paris.

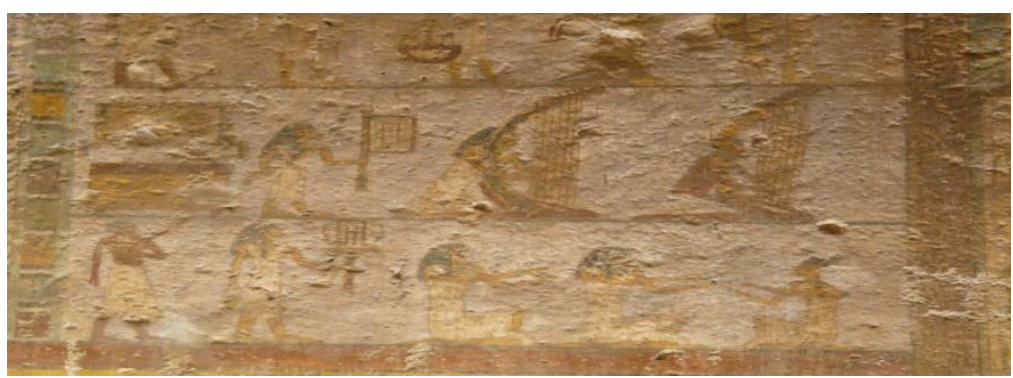

Figure 5. Female musicians, tomb of Amenemḥat, no.2, west wall, Beni Hassan, 12th Dynasty, Middle Kingdom. Source: Photographed by the researcher 


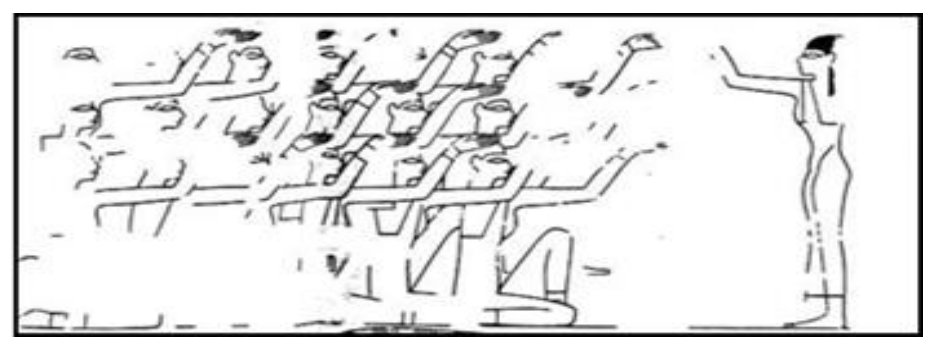

Figure 6. Female clapping class, women are facing their music director (tomb of Ukh-ḥotep son of Senbi, 12th Dynasty, Meir.

Source: Blackman, 1924, The Rock Tombs of Meir, vol. IV, VI London.

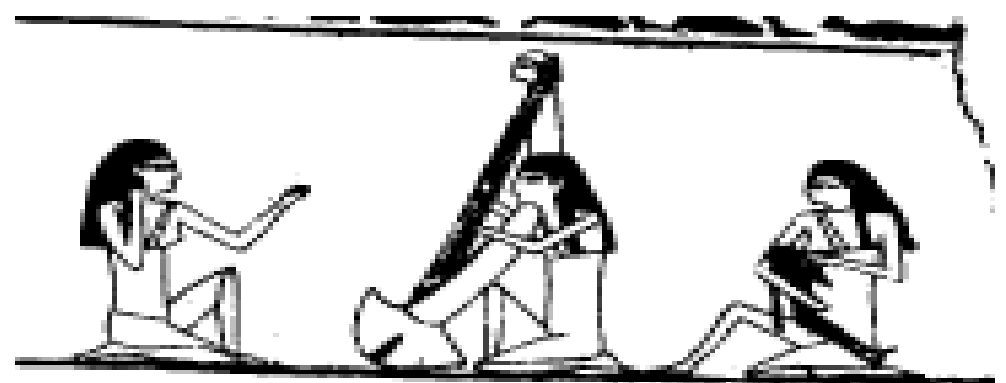

Figure7. A female musician playing on the harp and followed by another woman who was suckling her baby, tomb of Kheti (no. 17), south wall, at Beni Hassan, 11th Dynasty, Middle Kingdom.

Source: Newberry, P. E., 1893, Beni Hasan 2, London, pls. VII, XVI.

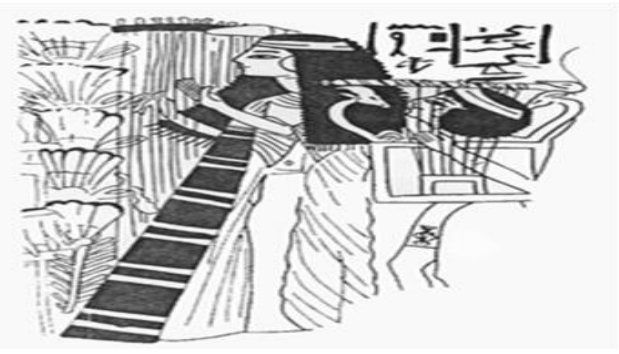

Figure 8. Dancing girl with the tattoo of god Bes on her thigh she also plays lyre with another female musician (tomb of Nebnakhet, 19th Dynasty, Thebes.

Source: Manniche, L., 1997, Sexual life in Ancient Egypt, London. 


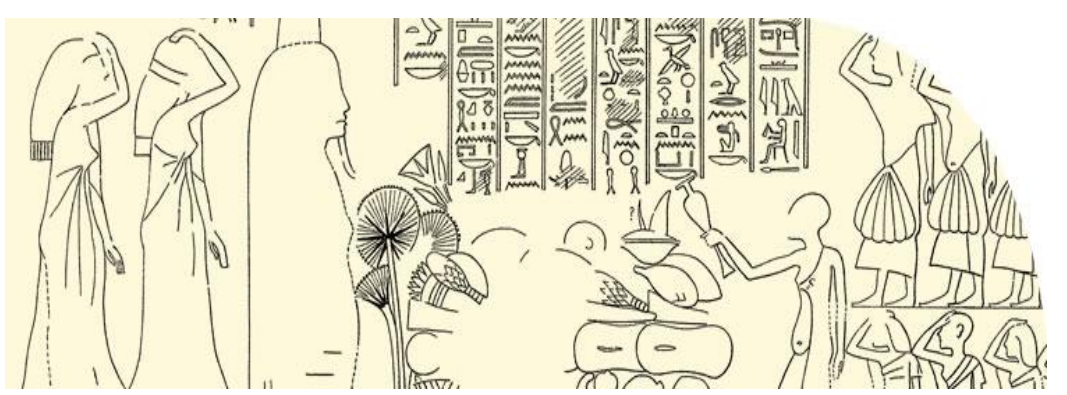

Figure 9. Female mourners depicted in the funeral procession of Huya, Tomb of Huya (no. 1), 18th Dynasty, Amarna.

Source: Davies, N. de G., 1905, The Rock Tombs of El-Amarna III, London, pl. XXII.

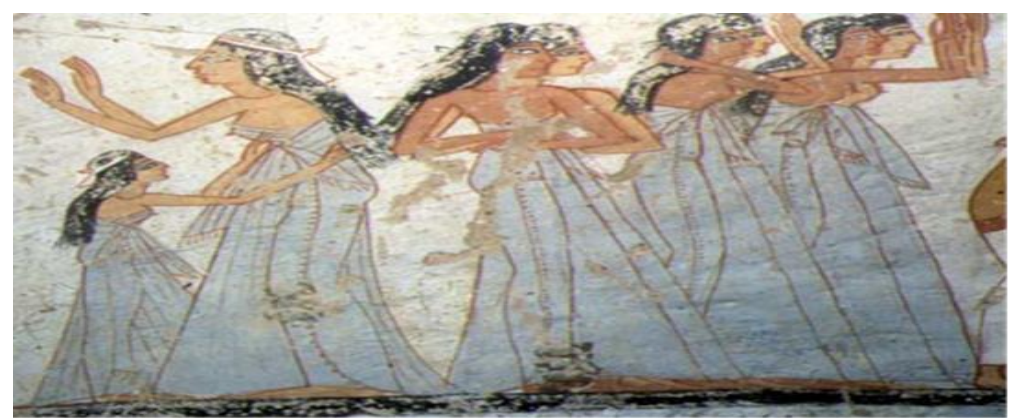

Figure 10. Female mourners with young girl mourner. They were wearing an ample uncommon grey-blue dress, fringed, and tied below the breasts, (tomb of Ameneminet TT277), 18th Dynasty, Qurnet-Murai at Thebes.

Source: Abdul-Kader M., 1966, The development of the funerary beliefs and practices displayed in the private tombs of the New Kingdom at Thebes, Ministry of culture, Cairo.

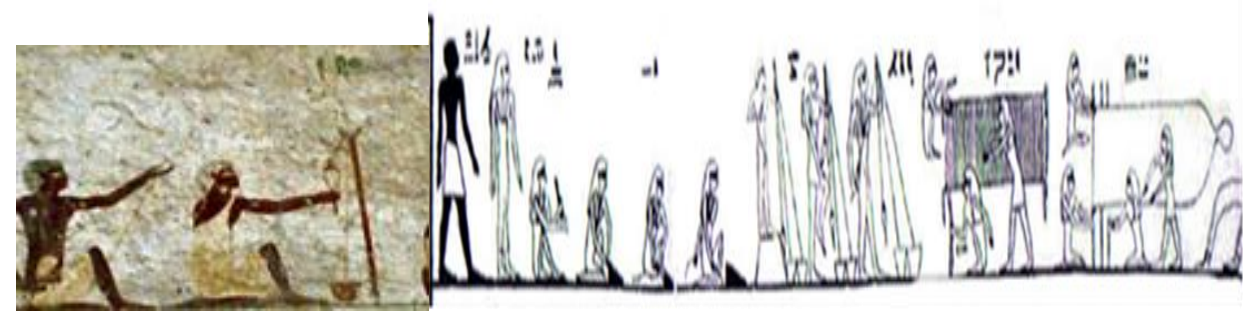

Figure 11. Women spinning and weaving, tomb of Baquet III (no. 15), North wall, Beni Hassan, 11th Dynasty, Middle Kingdom.

Source: Kanawati, N. and Woods, A., 2010, Beni Hassan. Art and Daily life in an Egyptian Province, Supreme Council of Antiquities, Cairo, pls. 132, 133. 


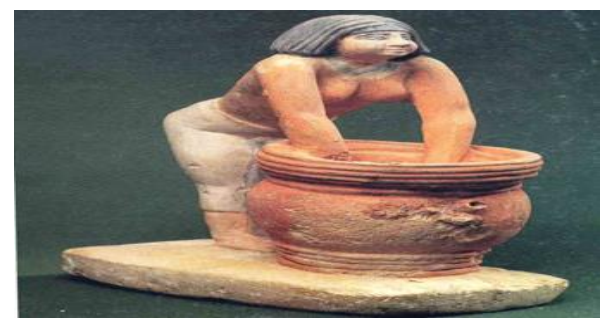

Figure 12. A painted limestone statue of a female brewer (Cairo museum JE 66624), found in tomb of Meresankh at Giza, 5th Dynasty, Old Kingdom.

Source: Scharff, A. (1941), On the Statuary of the Old Kingdom: The Journal of Egyptian Archaeology

Vol. 26 (Feb. 1941), 41-50.

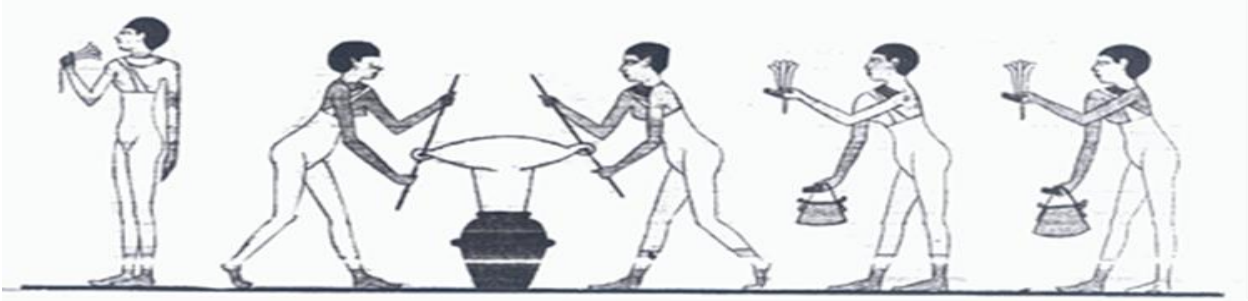

Figure 13. The Scene from Beni Hasan depicts group of five women well dressed, involving in the producing of perfume. The first two were holding flowers in their hands and bags in the other hand. The second two seem to be squeezing the flower wrapped in a piece of cloth. The last woman is standing

in front of them smelling a flower; she seems to be their supervisor.

Source: Klebs, L., 1922, Die Reliefs und Malereien de mittlern Reiches, Heidelberg.

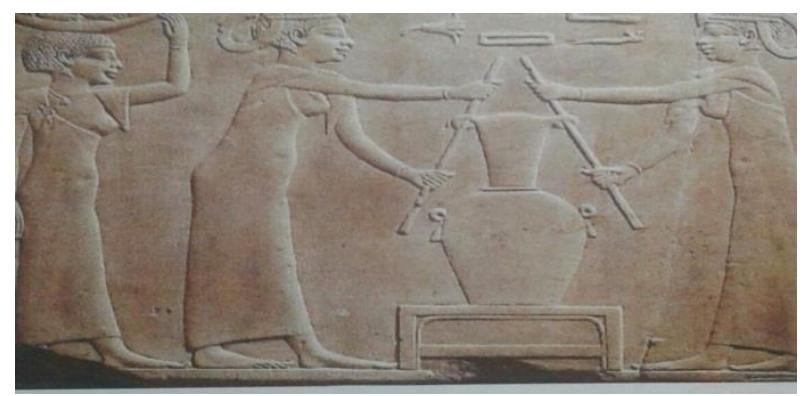

Figure 14. Two female perfumers in elegant dresses and hairstyles, squeezing lily blossoms in a large jar, 26th Dynasty, Late period.

Source: Manniche,L., 1999, Sacred Luxuries: Fragrence, Aromatherapy and cosmetics in ancient Egypt, London. 


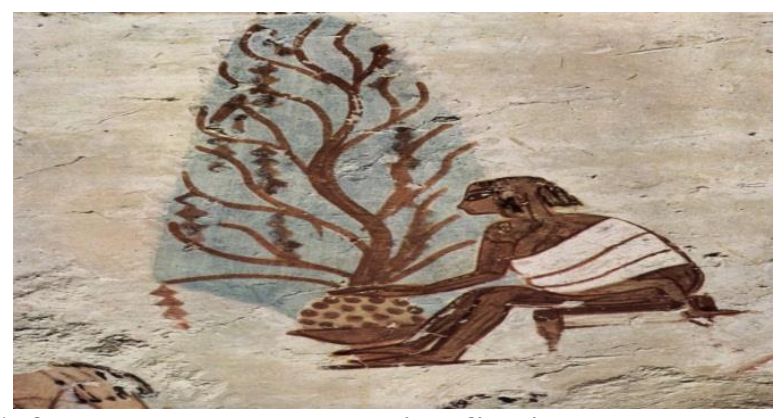

Figure 14. A female peasant harvesting figs in a shallow basket and suckling her infant in an agricultural context, tomb of Menna (TT69), Thebes, 18th Dynasty, New Kingdom.

Source: Hartwig M. (Ed), 3013, The Tomb Chapel of Menna (TT 69). The art, culture and science of painting in an Egyptian tomb: ARCE conservation Series 5, American University in Cairo Press.

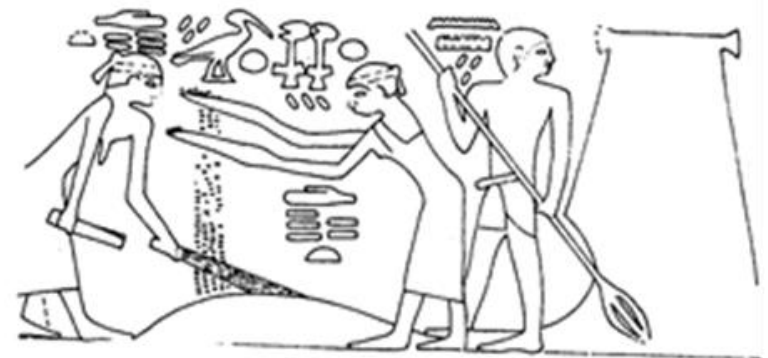

Figure 15. Two female winnowers (tomb of Niankhkhnum and khnumhotep, 5th Dynasty, Saqqara).

Source: James, A. (2006). Some aspects of the non-royal afterlife in the Old

Kingdom. The Old Kingdom Art and Archaeology: Proceedings of the Conference Held in Prague May 31 - June 4, 2004. Prague: Czech Institute of Egyptology.

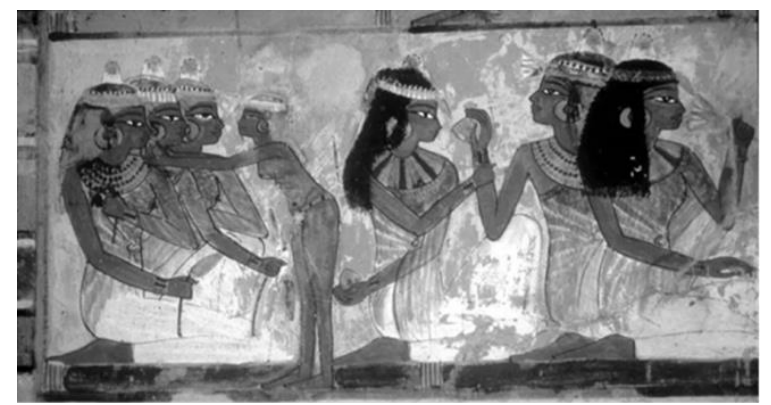

Figure 16. A Maidservant arranging an earring of a lady, (tomb of Nakht TT52,18th Dynasty, Thebes, www//osirisnet.net, accessed on 29/9/2019). 


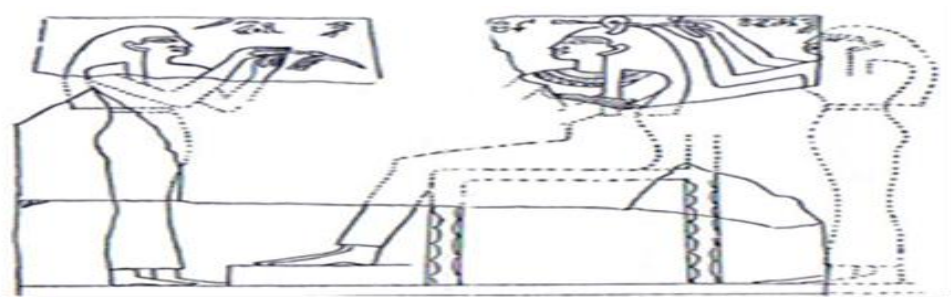

Figure 17. Two female hairdressers (tomb of Neferu, 11th Dynasty, Deir el Bahry). Source: Vandier,J., 1964, Manuel D’Archéologie Egyptienne. Tom.iv, Paris.

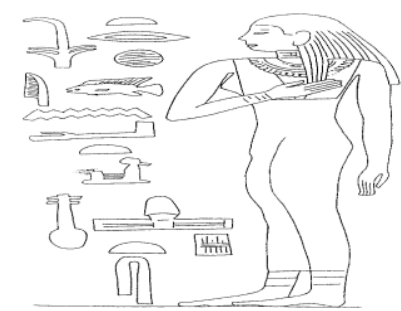

Figure 18. Hieroglifhic sign for midwife.

Source: Fischer, H., 2000, Egyptian Women of the Old Kingdom, New York.

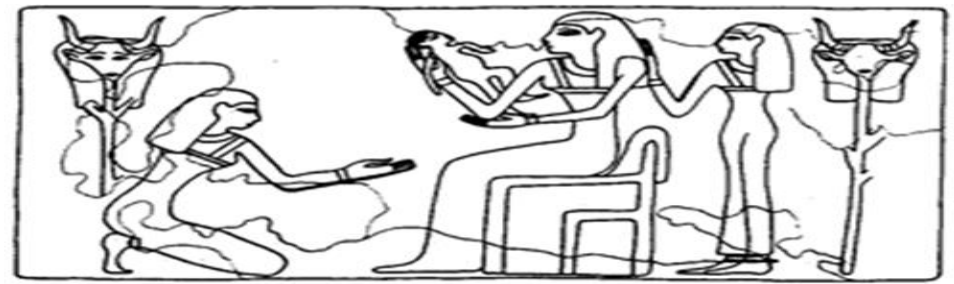

Figure 19. A midwife assisting in a newly born baby (a birth brick,13th Dynasty,Abydos)

Source: Wagner, J., 2002, A decorated Birth-brick from south Abydos: EES, n.21.

Figure 20. An old female supervisor holding a stick and over her head is the symbol of the 16th nome of Upper Egypt depicted punishing another woman in front of her, tomb of Baquet III (no. 15), south wall, 11th Dynasty, Beni Hassan.

Source: Photographed by the researcher. 